\title{
The OCA Theory and Its Empirical Application for the EMU
}

\section{Introduction}

Whether we like it or not, the theory of optimum currency areas (OCA) remains the workhorse for analyses of European monetary unification. The OCA theory, with its focus on asymmetric shocks, labor mobility and the transaction value of a single currency, subsumes but a subset of considerations relevant to the decision of whether to fix the exchange rate or form a monetary union.

The theory has advanced only minimally since the seminal contributions of Mundell [1961], McKinnon [1963] and Kenen [1969]. Nonetheless, it remains difficult to move from theory to empirical work and policy analysis. A popular device is to conclude a review of the theoretical literature by stating that "Europe is not an optimal currency area," without providing much analysis of how this situation is changing or of the comparative prospects of different countries.

The purpose of this paper is to advocate renewing empirical research in this area in the light of the canonical implications of the OCA theory. We attempt to evaluate the usefulness of the OCA indices - currently the main analytical tool. We also suggest that perhaps revisiting the supposedly "outdated" methodology of De Grauwe [1993, 1995], and verifying its performance against the OCA index benchmark, might actually provide some interesting insights. The importance of this approach seems particularly acute now that more than 12 countries are considering entering the European Monetary Union (EMU) sooner or later. The political arguments of the Maastricht criteria and the Growth and Stability Pact have shaped the directions of economic research. Currently, it is the monetary policy strategy that takes over the floor for discussion, narrowing the problems of prerequisites and the consequences of currency areas. Conformity with bureaucratic rules seems to overshadow synchronization, while optimality is narrowed to the Maastricht criteria (see: [Wyplosz, 2006]).

The paper is organized as follows. In the next section, we approach the issue of OCA indices and actual optimality. This problem has a deeper meaning in the

\footnotetext{
The author is an employee of the Chair of Development Economics at the Faculty of Economics, warsaw University. The first version of this paper appeared in February 2004. This version dates back to March 2007. The author wishes to thank C. Wójcik and R. Kokoszczyński, participants of ZEW Summer School 2005, as well as two anonymous referees for all comments. The usual disclaimer applies.
} 
hypothesis of business cycle synchronization, and this is tackled further in the paper. In the end, a simple econometric model investigating the potential impact of the EMU on European trade patterns points to some of the consequences of forming a currency area that are rarely mentioned in the literature. The paper closes with conclusions.

\section{OCA indices and optimality}

The seminal papers by Eichengreen and Bayoumi [1996, 1997] have marked a significant change in the methodology of research into real economic convergence. The progress in Optimum Currency Area theories has led scientists to adopt the index approach. These indices are based on trade/GDP ratios, measures of monetary convergence and business cycles correlation.

However, recent developments in the European Monetary Union point to some noteworthy shortcomings of this methodology. The two largest trading partners and by far the best candidates to form a currency union, the Netherlands and Germany, have proven to need completely opposite monetary policies in response to the global economic slowdown of 2001. German recession was accompanied by rapid economic growth in the Netherlands, which was literally "burned" by high inflation. French and Italian problems with fiscal stability and increasing unemployment were accompanied by a significant budget surplus in Ireland and falling unemployment rates in Spain and Greece.

The synchronization of business cycles - a beautiful phrase often used by both economists and politicians - has become a real economic and political problem to be solved. Surprisingly, this problem has been especially severe in the case of Germany and the Netherlands - the least expected places from the point of view of OCA index-driven reasoning.

The initial approach to analyzing the issue of real convergence, as introduced and developed by De Grauwe [1993, 2000, 2005], focused on differences in the volatility of GDP growth rates and labor market flexibility.

Research in this area has led to the conclusion that the EMU12 is not an optimal arrangement and that the only stable monetary union should probably consist of Germany, the Benelux countries and possibly France ${ }^{1}$. This conclusion, though politically unfavorable and still tying the German and Dutch economies together, has shown that some serious economic problems should be expected on the road toward real convergence among EMU economies.

\section{Where have the labor markets gone?}

Moreover, Europe has consistently been plagued by insufficient labor market flexibility. It is not trade or capital exchange that lags behind the overall integration within the EU. Understanding better how the interactions between

1 The presence of France was strongly opposed by Eichengreen and Bayoumi [1996]. 
labor markets and the rest of the economy might affect the stability of the EMU seems to be an issue worth analyzing.

What other answers can we find within this abandoned methodology in which assessments are based on labor market flexibility and real business cycle volatility? Most of the new EU member states are eager to join the EMU as well. In terms of typical OCA index analysis, some of them, like Slovenia or Estonia, are already at the current EMU member state levels. Obviously, they need at least another two years to fulfill the Maastricht Treaty criterion of exchange rate stability, but others do not seem to be able to reach this level within the next two years.

The impending decisions on enlarging the EMU, as always in such cases, will largely be political. However, the OCA index analysis seems to overlook the fact that admitting new countries to the EMU changes the characteristics of the currency area. The overall asymmetry of response to external shocks may either decrease or increase. On the other hand, inter-country differences may grow drastically. Moreover, the situation is fully dynamic as the convergence process continues.

Are there any answers to be found in the initial approach to monetary integration, as suggested by De Grauwe [1992]? Why has labor mobility disappeared from the considerations, when OCA indices marched into the literature? Based on production differentiation and market elasticity, can we seek any better method for assessing the optimality of a currency area than a mechanical index incorporating trade shares, inflation, interest rates and the correlation of GDP growth rates?

\section{Synchronicity in Europe}

Some insights into the claim of European business cycles synchronization may be drawn from the financial approach of downside risk analysis. As has been repeated many times in the context of EMU formation, "if everything's fine, everything's fine", and the problems only arise when negative shocks occur. Synchronization is often measured by business cycle correlation. Is this measure suitable for answering the questions that are naturally raised by policymakers and advisors, i.e. whether EMU economies are becoming more alike and consequently whether the EMU (or an enlarged EMU, for that matter) is economically sustainable?

The issue of shock asymmetry has received particular attention due to the development of the OCA theory. According to canonical OCA criteria, two countries or regions would benefit from forming a monetary union if they are characterized by a high similarity of business cycles, have strong trade links, and if they possess an efficient adjustment mechanism ${ }^{2}$ that can mitigate the adverse effect of asymmetric shocks. The first criterion is often considered to be the key one.

2 e.g. labor mobility, flexibility of factor prices, and a system of fiscal transfers. 
Indeed, if the business cycles of two countries are highly synchronized, or, in other words, if the countries share a response to a shock, a common monetary policy does not introduce imbalances between these countries. Much interest, therefore, has been focused on the estimation of the degree of shock asymmetry between countries or regions. Along with the measurement issue, another question concerns the determinants and the mechanism of shock propagation. Trade and exchange rate regimes are two channels: a real one and one that can transmit shocks from one country to another.

\section{The endogeneity hypothesis}

Frankel and Rose [1998] open a large debate on the endogeneity of OCA criteria fulfillment. They put forward an argument that closer trade links could lead to business cycle synchronization and thus increase the symmetry of shocks. Or should we consider shock responses instead? According to traditional points of view ${ }^{3}$, the opposite effect should prevail: international trade increases specialization, making shocks more asymmetric. The overall impact of trade integration on shock symmetry could thus be ambiguous, at least theoretically. Modern formal models of optimum currency areas do not seem to offer a unique answer either ${ }^{4}$. Frankel and Rose [1998] stress the necessity of further analysis of the role of international trade by distinguishing between inter-industry and intra-industry trade. Inter-industry links reflect specialization, thus potentially causing asymmetries, while intra-industry trade should lead to business cycle co-movement. There is an ongoing theoretical work in this direction ${ }^{5}$.

The concept of integration can be considered in a broader sense, including monetary integration as well. Ricci [1997a] builds a two-country model of the optimum currency areas, which incorporates monetary and real variables. One of the model's key implications is that "the adoption of fixed exchange rates endogenously increases the desirability of this currency area by reducing the shock asymmetry". Note that in Ricci's model exchange rates affect shock asymmetry indirectly, through trade: flexible exchange rates favor specialization compared with fixed rates. This means that exchange rate arrangements may matter for business cycles correlation, at least to the extent that specialization leads to asymmetric responses ${ }^{6}$.

A number of empirical studies focus on measuring the degree of shock asymmetry across countries. In earlier research, judgment about shocks was based on the cross-country correlation of real output, industrial production,

\footnotetext{
e.g. Krugman [1993].

see Ricci [1997b]; see also Horvath [2002b], pp. 21-23, for a recent review of OCA models. see, among others, Kose and Yi [2001].

6 Naturally, other determinants beside bilateral trade, its specialization patterns and exchange rate regimes may influence business cycle transmission between countries. One might think about tariffs and non-tariff barriers, institutional agreements, border effects etc.
} 
or real exchange rate cycles ${ }^{7}$ Such an approach, however, does not allow one to distinguish between shocks themselves and reactions to shocks. Since both components are present in actual series, similar results in terms of correlation coefficients might be observed in the presence of various combinations of shocks and responses to shocks.

\section{Measuring the symmetry of shock response}

Blanchard and Quah [1989] propose a bivariate vector autoregressive (VAR) procedure in order to separate shocks from responses. Moreover, this method makes it possible to identify the origins of shocks, for example supply and demand. Blanchard and Quah [1989] define shocks as linear combinations of the residuals from a bivariate VAR representation of the real output growth and inflation. By construction, one type of shocks (labeled as "demand" shocks) have an only transitory impact on the level of output, while another type of shocks (labeled as "supply" shocks) might have a long-term impact on the level of output. More precisely, if real output and prices are used as inputs to the VAR model, then "demand" shocks are defined so that they do not have a long-term impact on either output or prices, while "supply" shocks might have a long-term effect on output. It is crucial to understand that "supply" and "demand" are rather theoretical labels than an empirical recognition of the shock origin. Nevertheless, VAR decomposition has become an especially popular tool in identifying shocks to assess the similarities of economic cycles in the case of European monetary integration.

Later, measuring co-movements of shocks across countries and regions was used for the assessment of OCA criteria. For example, a high correlation between two countries' series of shocks indicates that the economic structures of the countries under consideration are quite similar. This methodology allows Bayoumi and Eichengreen (1996) to identify "core" European countries for which the cost of a common monetary policy could thus be low. Note that the coefficient of correlation of shock series represents a static measure. Therefore, it is difficult to judge if shocks become more symmetric or not.

However, since the degree of economic integration changes over time, there are few reasons to believe that shock asymmetry remains constant. The dynamics can be partially assessed by splitting the whole period and calculating the correlation coefficient by sub-periods, provided that sub-intervals are long enough.

There is, however, more fundamental critique to this approach. Fontagne and Freudenberg (1999) argue that "the central critique to be addressed to studies based on VAR estimates of asymmetric shocks refers to the assumption of structural asymmetries. The only way to relax this assumption is to use a Kalman filter in order to tackle the issue of a dynamic convergence of

7 see, for example, Cohen and Wyplosz [1989], Weber [1991], De Grauwe and Vanhaverbeke [1993], Artis and Zhang [1995]. 
shocks". Boone [1997] applies the Kalman filter technique in order to obtain time-varying estimates of shock symmetry. Her results for Western European countries are consistent with those reported by Bayoumi and Eichengreen [1996] and, notably, give ample information about the dynamics of evolving symmetries. The results are generally interpreted in favor of the endogeneity hypothesis: the observable increase in the supply and demand shock correlation goes along with deepening European integration.

An increasing number of studies focus on the analysis of symmetries between current European Union members and accession countries ${ }^{8}$. Supply and demand shocks are extracted from quarterly series of the real output and prices. Short time series (less then 10 years of quarterly observations) complicate the econometric analysis9.

Babetski, Boone and Maurel [2002] extend the analysis of supply and demand shocks by measuring the time-varying correlation in a way advocated by Boone [1997]. Their results stress an ongoing process of demand shock convergence between the EU and accession countries. Supply shocks tend to diverge, which is interpreted as a due restructuring process at work and the Balassa-Samuelson effect.

\section{But how do we compare shocks?}

So far the debate has centered on the measurement issue, namely how to identify shocks and how to measure the cross-country correlation of disturbances. One serious issue has been omitted. A natural question concerns the determinants and sources of the observable increases or decreases in shock symmetry. To some extent, all the studies mentioned above try to discuss factors that drive the cycle symmetries or asymmetries. Integration in various interpretations of this broad concept is often said to be the key factor that affects the understanding of business cycle co-movements. Yet such a potentially important explanatory variable is missing from the analysis. This is the subject to which we now turn.

8 Fidrmuc and Korhonen [2001], Horvath [2002a], Babetski, Boone and Maurel [2002] follow the structural VAR identification methodology developed by Blanchard and Quah [1989] and Bayoumi and Eichengreen (1996). Horvath (2002a) concludes that the correlation of neither demand nor supply shocks can be interpreted in favor of convergence. Fidrmuc and Korhonen [2001] find that supply shock correlations vary substantially from country to country. The correlation of demand shocks between the EU and the CEECs is substantial for Hungary and Estonia, while other accession countries show modest results. Compared to earlier studies for Western European countries, the current results indicate an increase in synchronization between the EU "core" and Italy and Portugal, which were previously considered to be "peripheral" countries.

9 Naturally, other determinants beside bilateral trade, its specialization patterns and exchange rate regimes may influence business cycle transmission between countries. One might think about tariffs and non-tariff barriers, institutional agreements, border effects, etc. 
Frankel and Rose [1998, 2000], in their influential work, argue that international trade increases the convergence of business cycles. The estimates are performed on a large cross-section of OECD countries over 30 years, and the results seem very robust to the choice of indicators of bilateral trade and business cycles. Trade, represented by either exports, imports or total bilateral volumes, is further confronted with intra-industry trade. Although not directly tested, it is the latter that is said to be particularly relevant for business cycle convergence. An additional inclusion of the exchange rate regime dummy does not qualitatively change the results.

Nonetheless, at least one important question remains after reading the article by Frankel and Rose [2000]. All the constructed business cycle indicators belong to the same class. Namely, they represent de-trended indicators of economic activity. Hence, shocks and the responses to shocks enter the analysis together. Kenen [2001] argues that the results are biased since trade, a real variable, is not exogenous to fluctuations of another real variable like economic activity. Kenen sketches a simple Keynesian framework where the correlation of countries' business cycles is determined by bilateral trade intensity 10 .

Using disaggregate trade data, Fontagne and Freudenberg [1999] find evidence that exchange rate variability depresses intra-industry trade, and should consequently lead to a higher symmetry of shocks, as they argue.

Based on historical data, Flandreau and Maurel [2000] argue that there is a positive impact of both monetary arrangements and trade on business cycle correlation.

This analysis of the literature is far from complete. However, looking at these and other studies not discussed here, one can note a surprising segmentation in research interests. Two entirely separate classes of studies seem to coexist: those focused on measuring the correlation of shocks, and other studies concentrated on assessing the link between business cycle fluctuations and trade, exchange rate and other explanatory variables.

More specifically, studies of the first group illustrate static or dynamic patterns of shock correlation, stressing the importance of distinguishing between shocks and responses to shocks. Studies of the second group identify the effects of trade and other variables on various business cycle indicators containing both shocks and responses to shocks. To our knowledge, there are no direct estimates of the determinants of shock asymmetry.

Babetski [2004] tries to make a bridge between these two groups of studies, by confronting time-varying estimates of shock asymmetry with trade and exchange rate variables. This paper supports the hypothesis about demand shock

10 Fidrmuc [2001] re-estimates the specification of Frankel and Rose (1998), focusing on a cross-section of OECD countries over the last 10 years and working with different frequencies (quarterly data). Aware of Kenen's [2001] criticism, Fidrmuc [2001] reconfirms the interpretation by Frankel and Rose [1998] and bypasses Kenen's criticism. This is done by direct inclusion of intra-industry trade into the regression. Thus, according to the main point of Fidrmuc [2001], it is the particular structure of trade that matters for business cycles transmission. 
convergence and the divergence of supply shocks between candidate countries, the EU-15, and Germany as alternative benchmarks. Estimated time-varying coefficients of shock asymmetry are then confronted with several indicators of bilateral trade intensity and exchange rate volatility. The results are in line with Frankel and Rose's [1998] endogeneity hypothesis, stating that countries are more likely to satisfy criteria for a monetary union membership ex post, as economic integration deepens.

It follows that pegging national currencies to the euro or even entering the EMU would not be so costly for candidate countries, in terms of costs associated to shock asymmetry. Indeed, EU candidate countries are characterized by levels of supply and demand shock asymmetries comparable to those for the present EU member countries such as Ireland, Portugal and Spain. However, even this vast study settles for noting increasing correlations of business cycles, while overlooking a typical pattern of increasing variability at times of an economic slowdown. This seems to be a major drawback of this form of research.

The costs to coordinated monetary policy occur only when an asymmetric shock actually arises. In other words, synchronization is not that much of an issue at times of economic prosperity. Since shocks are of different magnitude, the only way of measuring the actual convergence of European business cycles would be to compare the response to shock (sensitivity) in time. But how should one compare the size of shocks? Is a smaller impact on GDP growth rates the result of a smaller shock or a better suited policy?

There is no empirical answer to this question in the area of real business cycles. However, the financial analysis of downside risk may be applied here providing some potentially useful insights. Furthermore, to some extent, these measures can be at least partly dynamic in nature, allowing for a closer match between the method and the nature of the process. Thus, this type of measures should be better suited to answering the questions economics asks.

\section{EMU and trade}

Following Frankel and Romer [1999], an attempt was made to verify in the model whether the institution of a common currency, introduced in the form of the European Monetary Union in 1999, has had any impact on the patterns of trade among its members.

\section{Empirics of the trade: exchange rate volatility relation}

The natural presumption would imply that, through the elimination of currency volatility and the resulting process of eliminating exchange rate risk, the propensity to trade would be enhanced. There are, however, some obstacles to adopting this view. First of all, in the case of developed countries, financial markets provide instruments allowing for a relatively inexpensive hedge, thus 
eliminating any risk at all, at least in theory ${ }^{11}$. Secondly, currency volatility between EMU countries is not very bothering to trade partners, as it rarely exceeded the $4.5 \%$ corridor over the period of the past eight years.

The effects of exchange rate volatility on trade are ambiguous. In particular and perhaps contrary to intuition, it is not certain that exchange rate volatility must reduce trade. Empirically, the results are also ambiguous and depend, among other things, on the methodology employed. Early research based on time series estimation produced contradictory results. On balance, trade seems to be essentially unaffected, or, if the estimates are significant, only marginally affected by exchange rate volatility. But more recent research based on modern time series methods delivers results that are less ambiguous; most of the studies estimate negative and substantial effects both in the short and the long run [Chowdhury, 1993], [Bini-Smaghi, 1991].

In Europe, however, Harry Flam and Per Johnson [Flam and Jansson, 2000] aimed at examining the partial effect of the nominal exchange rate volatility on exports from each EMU member state to the rest of the zone.

The main goal of this study was to estimate the effects of nominal exchange rate uncertainty on trade between member countries before the start of the EMU (time series from 1967 to 1997). By doing so, they hoped to get an idea of the qualitative and quantitative effects of eliminating nominal exchange rate uncertainty. The long-run relations between exchange rate volatility and exports turned out to be mostly negative, but in a vast majority of cases insignificantly different from zero.

Enthusiasts of the currency union concept treat it as the ultimate credible commitment to a stable monetary policy. Among frequently mentioned benefits are: enhanced central bank credibility, superior inflation performance, and deeper financial markets, all of which are believed to increase productivity and hence output. Also, the issue of size is often raised. First of all, it is not irrelevant whether a country adopts the currency of a smaller or a larger partner (in most cases the latter occurs), as size matters. Countries naturally tend to trade more with larger neighbors, hence raising the benefits of adopting the currency of a larger country. On the other hand, there are also possible drawbacks of the possible impact of the currency union on trade. First, one should bear in mind the danger of exclusion. It is likely that, similar to the customs union case, there may exist a negative effect of trade diversion from

11 Forward hedging, the cheapest available solution, costs up to $2.5 \%$ of the basic transaction and is therefore profitable only for medium and large volumes of trade. In addition, the flexibility of derivative instruments is limited mostly to standardized contracts. The unusual execution dates and conditions are available but starting at a certain level of volume, constructing an instrument for the turnover of 10,000 or even 100,000 euros annually is implausible. Therefore, for small businesses, the chances of covering their exchange rate risk are limited. These aspects are often omitted in literature. An illustrative example of the cost of currency exchange given in the Jacques Delors report also seems worth mentioning: if a bill of some denomination would have been exchanged successively into all the other currencies in the EU and then back to its original denomination, half of the value would have been lost. 
more risky partners (i.e. those who still bear the burden of exchange rate risk) to the less risky ones. The aspect of the transmission channel also seems important here. It is possible that by minimizing transaction costs, and thus raising income, the resulting increase in GDP will cause an eventual increase in trade, as indicated by Frankel and Rose [1998].

Summarizing, literature on the subject is significant. However few publications refer directly to the case of the EMU. Unfortunately, we will have to wait a few more years to give any robust conclusions concerning the euro, as little data on the EMU is currently available. Moreover, the liaisons and linkages within Europe seemed so strong and old that the existing trade patterns seem rather unlikely to be strongly affected by the change in the transaction method. Nevertheless, as the introduction of the common currency is one of the major achievements of European integration, and, as such, it appears to be a very important institution, we decided to analyze it in our model as well.

\section{The model}

The estimated model is a simple gravity equation in the form of:

TRADEi, $\mathrm{j}, \mathrm{T}=\mathrm{GDPi}, \mathrm{j}, \mathrm{T}+$ POPULATIONi,j,T + DISTANCEi, $\mathrm{j}$ + COMMON BORDERi,j + COMMON LANGUAGEi,j + COMMON CURRENCYi,j,T + €T.

It was estimated on a sample of bilateral trade data from Eurostat. The left-hand side is given by bilateral trade for $15 \mathrm{EU}$ member states before the enlargement and unbalanced data for the accession countries for which mutual exchange data are missing. The time range captures the period of 1989-2003. To eliminate the possible effects of other factors, we control standard gravity equation determinants. Namely, we wanted to control for a common border effect (dummy) as well as a common language as a factor facilitating exchange (dummy for official languages). In addition, we wanted to incorporate the consequences of geographic distance (measure after [Chen, 2002]). Canonical control factors like population (measure of market size) and GDP (measure of economy size) are also included.

In each case, results from the most accurate model are reported, i.e. once all insignificant variables were eliminated. Neither heteroscedascity nor autocorrelation were found in the sample, when year was chosen as a grouping variable. Also, no problem of multicollinearity occurred.

Standard errors reported in parenthesis. ${ }^{* * *}, * *$ and $*$ indicate statistical significance at the 1,5 and 10 percent level, respectively. 
Table 1

Dependent variable: Bilateral trade (in logarithms)

\begin{tabular}{|l|c|c|c|c|}
\hline Independent variables & $(1)$ & $(2)$ & $(3)$ & $(4)$ \\
\hline \multirow{2}{*}{ GDP (in logs) } & 0.74 & 0.75 & 0.73 & 0.65 \\
\cline { 2 - 5 } & $(0.07)^{* * *}$ & $(0.07)^{* * *}$ & $(0.08)^{* * *}$ & $(0.08)^{* * *}$ \\
\hline \multirow{2}{*}{ Population (in logs) } & 0.54 & 0.56 & 0.65 & 0.67 \\
\cline { 2 - 5 } & $(0.07)^{* *}$ & $(0.08)^{* * *}$ & $(0.08)^{* * *}$ & $(0.08)^{* * *}$ \\
\hline \multirow{2}{*}{ Common border } & 0.22 & 0.26 & 0.23 & 0.24 \\
\cline { 2 - 5 } & $(0.09)^{* * *}$ & $(0.09)^{* * *}$ & $(0.16)^{* * *}$ & $(0.09)^{* * *}$ \\
\hline \multirow{3}{*}{ Common language } & -0.12 & 0.26 & 0.24 & -0.04 \\
\cline { 2 - 5 } & $(0.09)$ & $(0.19)$ & $(0.11)$ & $(0.072)$ \\
\hline \multirow{2}{*}{ Distance } & -0.0008 & -0.0008 & -0.0011 & -0.0008 \\
\hline \multirow{2}{*}{ Common currency } & $(0.00)^{* * *}$ & $(0.00)^{* * *}$ & $(0.00)^{* * *}$ & $(0.00)^{* *}$ \\
\cline { 2 - 5 } & 0.26 & 0.19 & 0.27 & 0.24 \\
\hline \multirow{2}{*}{ Constant } & $(0.16)^{*}$ & $(0.09)^{* * *}$ & $(0.11)^{* * * *}$ & $(0.08)^{* * *}$ \\
\hline R2 overall & -4.80 & -5.08 & -4.74 & -4.81 \\
\hline R2 within & $(0.22)^{* * *}$ & $(0.24)^{* * *}$ & $(0.12)^{* * *}$ & $(0.26)^{* * *}$ \\
\hline Number of observations & 0.87 & 0.85 & 0.67 & 0.69 \\
\hline F-statistic & 0.82 & 0.81 & 0.62 & 0.63 \\
\hline
\end{tabular}

Note: Fixed effect panel data estimation, with the year as a grouping variable. Log of trade is the dependant variable. Year and pair of country dummies not reported.

\section{The results}

The column (1) represents the sample of EMU member states over the entire time span. As we may observe, the common currency dummy is only marginally significant, albeit with the wished, positive sign. All control variables have the expected signs and are of standard magnitudes. The low significance of the common language dummy may be justified by the very high level of education in Europe as well as the relative weakness of this measure versus more sophisticated indicators, as suggested by Jacques Melitz [2000].

However, this selection is highly unbalanced - by definition we consider many more observations where the currency dummy takes the value of zero than where it takes the value of one. Therefore, we have decided to limit our time scope to 1993-2005. We further included EU member states that did not accept the euro as a common currency (i.e. Denmark, Sweden and Britain). These results are presented in column (2). The statistical significance of the common currency dummy has vitally increased. So has the economic one with the raising magnitude of the estimator. We see that both the R2 and the F- statistic of the model increased suggesting a better fit. 
This may also indicate that although the euro does not directly stimulate international exchange for its users, it diverts trade from partners for whom the volatility risk is still at play.

We further incorporated the accession countries to the model, and these results are given in columns (3) and (4).

Again, in column three, we analyze the whole time span, while in the last one we only consider the years 1993-2005. We may observe that both the statistical and economic significance of the euro zone dummy increases with the narrowing of the time span. Furthermore, the estimator in column (4) is significantly higher than in column (2), corroborating the above conclusion of the trade diversion effect.

The trade diversion hypothesis is an important trace rarely raised in the literature. Statistically, incorporating countries that do not belong to a currency area plays a role similar to a chemical filter - it emphasizes some patterns that are not visible enough otherwise. Based on these results, another important policy implication may be drawn.

Namely, staying outside the EMU ushers an additional cost of forgone international trade. The magnitude of this effect is rather difficult to be measured, but nevertheless is certainly highly significant from a statistical point of view.

These results seem to conform to the findings of Flam and Nordstrom [2006], who compare the SITC (one-digit) sectoral trade dynamics for EMU members and countries outside this currency area. They demonstrate that growth in trade has been considerably higher among EMU members than outside the euro zone (controlling for all important factors in a gravity model). This discrepancy ranges from $15 \%$ in the EMU to $8 \%$ outside, while tends to grow with time. They also demonstrate that most of this differential can be attributed to the highly processed industrial sectors, where vertical specialization seems to be more intense.

\section{Conclusions}

In this paper, the simple empirical model of gravity equation served as an excuse for reviewing the modern literature on the empirical research into the nature of the current and potentially enlarged European Monetary Union. This was pursued from the angle of the canonical Optimum Currency Area theory in search for new methods of arriving at empirical questions. The presented model, though very simple in nature, suggests a trend rarely raised in the literature, i.e. the possible trade diversion effect due to introducing a common currency area.

Should the CEECs join the EMU? The answer to this question has already been determined by both economists and politicians - by joining the EU, the CEECs have agreed to eventually join the EMU, which few serious economists find to be harmful to their economies. However, the actual moment of joining the currency union has not been determined, and to some extent its choice is 
left to the decision of Polish local policymakers. When should, for instance, Poland join the EMU, then?

Obviously, there are some costs to entering the currency union, as well as some benefits. However, since both the process of accession and the very participation in the EMU are dynamic in nature, the path to monetary integration with Europe is an issue that is worth exploring. There is no complete methodology for measuring the costs and benefits. Theoretically, they are cohesively explained, but empirically there are still many questions that have been left unanswered. Preferably, one would want to define a path for costs, another for benefits, find the net welfare values and integrate it over time to obtain the largest value. This way economics could provide a clear and simple way of unequivocally determining the optimal date of joining the EMU by the Czech Republic - per esempio on September 17, 2008.

Fortunately, as stated before, no such methodology exists or can exist. Furthermore, the definition of optimality has not been equivocally determined, as it largely depends on the assumptions underlying the empirical inquiries.

However, it is tempting to ask the question: under the following - explicit and implicit assumptions - when would it be best for Estonia, for instance, to join the EMU? Furthermore, is it also optimal for current EMU and other new member states? How reliable are these assumptions when confronted with the real-world situation? Can economics do better in these fields? All these questions are crucial not only for policy implication but also for further developments in the area of integration economics.

\section{Bibliography}

Aldenderfer M.S., Blashfield R.K., [1984], Cluster Analysis, Sage Publications, Beverly Hills, Ca., USA.

Artis M., Zhang W., [1995], International Business Cycles and the ERM: Is There a European Business Cycle?, „CEPR Discussion Paper”, No. 1191, August.

Babetski I., [2004], EU Enlargement and Endogeneity of some OCA Criteria: Evidence from the CEECs, „Czech National Bank Working Papers”, No. 2.

Babetski J., Boone L., Maurel M., [2002], Exchange Rate Regimes and Supply Shocks Asymmetry: The Case of the Accession Countries, „CEPR Discussion Paper”, DP3408, June.

Babetski J., Boone L., Maurel M., [2003], Exchange Rate Regimes and Supply Shocks Asymmetry: The Case of the Accession Countries, „CERGE-EI Working Paper”, No. 206, January (also forthcoming in the Journal of Comparative Literature).

Barro R.J., Gordon D.B., [1983], Rules, Discretion and Reputation in a Model of Monetary Policy, „Journal of Monetary Economics” 12, 101-121.

Bayoumi T., Eichengreen B., [1993], Shocking Aspects of European Monetary Integration, [in:] F. Torres, F. Giavani (eds.), Growth and Adjustment in the European Monetary Union, Cambridge, UK, Cambridge University Press and CEPR, pp. 193-230..

Bayoumi T., Eichengreen B., [1996], Optimum Currency Areas and Exchange Rate Volatility: Theory and Evidence Compared, [in:] International Trade and Finance New Frontiers for Research: Essays in Honor of Peter Kenen, (ed.) B.J. Cohen, Cambridge University Press, forthcoming.

Bayoumi T., Eichengreen B., [1997], Ever Closer to Heaven? An Optimum Currency Area Index for European Countries, „European Economic Review” (41) 3-5, pp. 761-770. 
Bini-Smaghi L., [1991], "Exchange Rate Volatility and Trade: Why is it so Difficult to Find any Empirical Relationship?, „Applied Economics” 23.

Blanchard O.J., Quah D., [1989], The Dynamic Effects of Aggregate Demand and Supply Disturbances, „American Economic Review”, September, pp. 655-673.

Bolton P., Roland G., [1997], The Breakup of Nations: A Political Economy Analysis, „Quarterly Journal of Economics" 112 (4), pp. 1057-1090.

Bolton P., Roland G., Spolaore E., [1996], Economic Theories of the Break-up and Integration of Nations, „European Economic Review” 40 (3-5), pp. 697-705.

Boone L., [1997], Symmetry and Asymmetry of Supply and Demand Shocks in the European Union: A Dynamic Analysis, „CEPII Working Paper”, No. 97/03, February (also published in Economie Internationale, in French),

Boone L., Maurel M., [1998], Economic Convergence of the CEECs with the EU, „CEPR Discussion Paper", No. 2018.

Boone L., Maurel M., [1999a], L'ancrage de l'Europe centrale et orientale a l'Union europenne (Targeting of the Central and Eastern European Countries to the European Union), „Revue conomique", Vol. 50, No. 6.

Boone L., Maurel M., [1999b], An Optimal Currency Area Perspective of the EU Enlargement to the CEECs, „CEPR Discussion Paper”, No. 2119.

Boreiko D., [2002], EMU and Accession Countries: Fuzzy Cluster Analysis of Membership, European University Institute.

Chen N., [2002], Intra-National Versus International Trade in the European Union: Why Do National Borders Matter?, „CEPR Discussion Paper”, No. 3407.

Chowdhury A., [1993], Does Exchange Rate Volatility Depress Trade Flows? Evidence From Error Correction Models, „Review of Economics and Statistics” 75, 1993.

Cohen D., Wyplosz C., [1989], The European Monetary Union: An Agnostic Evaluation, [in:] Macroeconomic Policies in an Interdependent World, R.C. Bryant et al. (eds.), International Monetary Fund, Washington.

Committee for the Study of Economic and Monetary Union, Report on Economic and Monetary Union in the European Community (Office of Publications of the European Communities Luxembourg), 1989, a.k.a. Delors Report.

Crowley P.A., et al., [2001], Is the US an OCA?, Southern Economics meeting in Tampa, Florida.

Culver S.E., Papell D.H., [1997], Is There a Unit Root in the Inflation Rate? Evidence From Sequential Break and Panel Data Models, „Journal of Applied Econometrics” 12 (4), 435-444.

De Grauwe P., [1992], Fiscal Discipline in Monetary Unions, „International Economic Journal”, Vol. 6, nr 1.

De Grauwe P., [1993], The Political Economy of Monetary Union in Europe, „The World Economy”, Vol. 16, No. 6, November.

De Grauwe P., [1995], The Political Economy of Monetary Union in Europe, „European Journal of Political Economy", Vol. 11.

De Grauwe P., [2000], Monetary Policies in the Presence of Asymmetries, „Journal of Common Market Studies", Vol. 38, Issue 4, p. 593-612.

De Grauwe P., [2005], Economics of Monetary Union, $5^{\text {th }}$ edition, Oxford University Press, Oxford, UK.

De Grauwe P., Vanhaverbeke W., [1993], Is Europe an Optimum Currency Area? Evidence from Regional Data, [in:] Policy Issues in the Operation of Currency Unions, P. Masson, M. Taylor (eds.), Cambridge University Press, Cambridge.

Dixit A.K., [1992], Investment and Hysteresis, „Journal of Economic Perspectives” 6-1, 107-132.

Dixit A.K., [1993], The Art of Smooth Pasting, „Fundamentals of Pure and Applied Economics”, Vol. 55, Harwood Academic Publishers, Amsterdam.

Dixit A.K., Pindyck R.S., [1994], Investment Under Uncertainty, Princeton University Press, Princeton, New Jersey. 
Fidrmuc J., [1999], Stochastic Shocks and Incentives for (Dis)Integration, „CEPR Discussion Paper”, No. 2104, Centre for Economic Policy Research, London.

Fidrmuc J., [2001], The Endogeneity of the Optimum Currency Area Criteria, Intra-Industry Trade, and EMU Enlargement, „LICOS Discussion Paper”, June.

Fidrmuc J., Korhonen I., [2001], Similarity of Supply and Demand Shocks Between the Euro Area and the CEECs, „BOFIT Discussion Paper”, No. 14.

Flam H., Jansson P., [2000], EMU Effects on International Trade and Investment, Institute for International Economic Studies, „Seminar Paper”, No. 683.

Flam H., Nordstrom H., [2006], Trade Volume Effects of Euro: Aggregate and Sector Estimates, Institute for International Economic Studies, Stockholm University, Seminar Paper No. 746.

Flandreau M., Maurel M., [2000], Monetary Union, Trade Integration and Business Cycles in 19th Europe: Just Do It, mimeo, later in CEPR Discussion Paper 3087.

Fontagne L., Freudenberg M., [1999], Endogenous Symmetry of Shocks in a Monetary Union, „Open Economics Review”, 10: 263-287.

Frankel J.A., Romer D., [1999], Does Trade Cause Growth?, „American Economic Review” 89(3).

Frankel J.A., Rose A.K., [1997], Is EMU More Justifiable Ex Post Than Ex Ante?, „European Economic Review", (41)3-5, pp. 753-760.

Frankel J.A., Rose A.K., [1998], The Endogeneity of the Optimum Currency Area Criteria, „Economic Journal" 108(449), July, pp. 1009-25.

Frankel J.A., Rose A.K., [2000], Estimating the Effects of Currency Union on Trade and Output, „NBER Working Paper”, No. 7857.

Gotour P., [1985], The Effects of Exchange Rate Volatility on Trade: Some Further Evidence, „IMF Staff Papers", No. 32.

Gros D., Thygesen N., [1998], European Monetary Integration, 2nd edition.

Hartigan J.A., [1985], Statistical Theory in Clustering, „Journal of Classification”, No. 2, 63-76.

Horvath J., [2002a], Supply and Demand Shocks in Europe: Large 4 EU Members, Visegrad 5, and Baltic States, ACE Phare Project No. P98 1061. The full text of the paper is available at http://econserv2.bess.tcd.ie/fidrmucj/

Horvath J., [2002b], The Optimum Currency Area Theory: A Review, ACE Phare Project No. P98 1061; http://econserv2.bess.tcd.ie/fidrmucj/ACE/Horvath2.pdf.

Kenen P.J., [1969], The Theory of Optimum Currency Areas: An Eclectic View, [in:] Monetary Problems of the International Economy, R.A. Mundell, A.K. Swoboda (eds.), University of Chicago Press, 41-60.

Kenen P.B., [2001], Currency Areas, Policy Domains, and the Institutionalization of Fixed Exchange Rates, Centre for Economic Performance, August.

Kose M.A., Yi K.M., [2001], International Trade and Business Cycles: Is Vertical Specialization the Missing Link?, „American Economic Review”, Vol. 91/2, pp. 371-375.

Krugman P., [1993], Lessons of Massachusetts for EMU, [in:] Adjustment and Growth in the European Monetary Union, F. Torres, F. Giavazzi (eds.), pp. 241-261, Cambridge, UK, Cambridge University Press and CEPR.

Lai K.S., [1997], On the Disparate Evidence on Trend Stationarity in Inflation Rates: A Reappraisal, „Applied Economics Letters" 4 (5), 305-309.

Lorr M., [1983], Cluster Analysis for Social Scientists, Washington, Jossey-Bass Publishers.

McKinnon R., [1963], Optimum Currency Area, „American Economic Review” 53, 717-725.

McKinnon R., [2002], Optimum Currency Area and the European Experience, „Economics of Transition" 10(2), 343-364.

Melitz J., [2000], Language and Foreign Trade, „CEPR Working Paper”, No. 3590.

Mundell R.A., [1961], A Theory of Optimum Currency Area, „American Economic Review” 51, pp. 657-665. 
Mundell R.A., [1973], Uncommon Arguments for Common Currencies, [in:] The Economics of Common Currencies, H.G. Johnson, A.K. Swoboda (eds.), Allen and Unwin, 114-132.

Nuti M.D. (ed.), [2002], A Symposium on Exchange Rate Regimes in Transition Economies: The Euroization Debate, „Economics of Transition” 10(2), 339-512.

Ricci L.A., [1997a], Exchange Rate Regimes and Location, „The International Monetary Fund Working Paper" 97/69.

Ricci L.A., [1997b], A Model of the Optimal Currency Area, „The International Monetary Fund Working Paper" 97/76.

Rose A.K., [2000], One Money, One Market: Estimating The Effect of Common Currencies on Trade, „Economic Policy”, Vol. 17, pp. 7-46.

Weber A.A., [1991], EMU and Asymmetries and Adjustment Problems in the EMS, [in:] The Economics of EMU, European Economy, Special Edition 1.

Wyplosz C., [2006], European Monetary Union: The Dark Sides of a Major Success, „Economic Policy", April 2006.

\section{THE OCA THEORY AND ITS EMPIRICAL APPLICATION FOR THE EMU}

\section{Sum mary}

The paper probes the notions of an "optimum currency area" (OCA) and "business cycle synchronization" in the context of convergence within the European Monetary Union (EMU). Analyzing the latest literature in this area, the author concludes that most of the measures currently used and promoted ignore the key advantages and disadvantages of an optimum currency area. At the same time, the paper attempts to apply a common tool of gravity equation to test the possible impact of the EMU on trade patterns among EU member states. By implementing a traditional notion of gravity equation, the author demonstrates that, as far as international trade is concerned, it is possible to move trade flows from non-EMU countries to those using the single European currency.

Keywords: optimum currency area, European Monetary Union, gravity equation, business cycle synchronization 